\title{
The Influences of Organizational Culture and Work Discipline to the Employee Performance (Case Study in PT.Sinarwijaya Ekapratista)
}

\author{
Surtiningsih Ryani Dhyan Parashakti \\ Faculty of Economics and business Universitas Mercu Buana
}

\begin{abstract}
The research aims to examine and analyze the influence of organizational culture and work discipline on employee performance. This study uses permanent employees at PT. Sinarwijaya Ekapratista, using saturated sample as a technique of determining the sample, in order to obtain a sample of 60 employees. The approach used in this research is Structural Equation Model (SEM) analysis tool SmartPLS. The results showed that organizational culture provide a positive and significant influence on employee performance. Then work discipline provides a positive and significant influence on employee performance.
\end{abstract}

Keywords: Organizational Culture, Work Discipline, employee performance, Structural Equation Model (SEM), Partial Least Square (PLS).

DOI: $10.7176 /$ RHSS/9-20-07

Publication date:October $31^{\text {st }} 2019$

\section{INTRODUCTION}

Human resources are essentially one of the main assets in an organization and play an important role in the success of an organization or company, because they are the driving forces of the organization in achieving the goals and objectives set by an organization. And to assess the quality of human resources itself can be measured from the level of work discipline and employee performance, because in an organization or company often produces different levels of work discipline and performance quality of each individual employee. Therefore, organizational productivity is largely determined by the productivity of the relevant human resources. And to realize this requires a good organizational culture.

The following can be seen the lack of work discipline for all employees from January 2018 - December 2018 employee attendance data as follows:

Tabel 1.1.Daftar Tabel Kehadiran Karyawan

\begin{tabular}{|c|c|c|c|c|}
\hline \multicolumn{4}{|c|}{ Tabel 1.1.} & \\
\hline Karyawan & Bulan & Terambat & Tidak Hadir & Pulang Awa \\
\hline & Januari & $147 \mathrm{kali}$ & 25 kali & 19 kali \\
\hline & Pebruari & $97 \mathrm{kali}$ & $14 \mathrm{kali}$ & $15 \mathrm{kali}$ \\
\hline & Maret & $124 \mathrm{kali}$ & $34 \mathrm{kali}$ & $26 \mathrm{kali}$ \\
\hline & April & $129 \mathrm{kali}$ & $21 \mathrm{kali}$ & $21 \mathrm{kali}$ \\
\hline & Mei & $127 \mathrm{kali}$ & $26 \mathrm{kali}$ & $18 \mathrm{kali}$ \\
\hline & Juni & $131 \mathrm{kali}$ & $32 \mathrm{kali}$ & $25 \mathrm{kali}$ \\
\hline 60 Karyawan & Juli & $138 \mathrm{kali}$ & $28 \mathrm{kali}$ & $23 \mathrm{kali}$ \\
\hline & Agustus & $116 \mathrm{kali}$ & 31 kali & $15 \mathrm{kali}$ \\
\hline & September & $127 \mathrm{kali}$ & $25 \mathrm{kali}$ & $21 \mathrm{kali}$ \\
\hline & Oktober & $121 \mathrm{kali}$ & $32 \mathrm{kali}$ & $16 \mathrm{kali}$ \\
\hline & Nopember & $114 \mathrm{kali}$ & $27 \mathrm{kali}$ & 22 kali \\
\hline & Desember & $103 \mathrm{kali}$ & 20 kali & $15 \mathrm{kali}$ \\
\hline Total tahun 2018 & & $1.474 \mathrm{kali}$ & $315 \mathrm{kali}$ & $236 \mathrm{kali}$ \\
\hline Sumber: PT.Sinar Wija & aprastita & & & \\
\hline
\end{tabular}

From the presentation of the data table above, it can be seen that there are still many employees who arrive late, do not attend and go home early. Due to the lack of maximum company regulations related to work discipline so that employees work not in accordance with company expectations. This work discipline will not have an impact on the performance produced by employees at PT. Sinarwijaya Ekapratista, work that should have been completed on time will be delayed because employees arrive late or are absent, and so they work not in accordance with the regulations set by the company.

So that employee performance has not fully run in accordance with the standards set by the company because the organizational culture that occurs in the company and the level of work discipline is still not good. Given these problems, the researchers are interested in knowing whether organizational culture and work discipline have an effect on employee performance at PT. Sinarwijaya Ekapratista. So the research title is as follows

"Analysis of Organizational Culture and Work Discipline on Employee Performance at PT. Sinarwijaya Ekapratista ". Based on the description above, the problems in this study can be formulated as follows: 
a. Is there an influence of organizational culture on employee performance?

b. Is there an influence of work discipline on employee performance?

\section{Research Objectives}

a. To determine the effect of organizational culture on employee performance.

b. To find out the effect of work discipline on employee performance.

\section{THEORY STUDY AND LOGICAL FRAMEWORK \\ Management of Human Resources}

Human resource management consists of two main notions, namely Management and Human Resources. Management means managing, managing, implementing, and managing. While human resources are one of the resources contained in the organization.

So, simply understanding human resource management is managing human resources. Of all the resources available in an organization, both public and private organizations, human resources are the most important and very decisive. The only resource that has ratio, taste, and intention.

The study of how to empower employees in the company, create jobs, work groups, develop employees who have the ability, identify an approach to be able to develop employee performance and reward them for their efforts and work (Bohlarander and Snell, 2010).

From the opinion of the expert, it can be said that human resource management is an activity of planning, organizing, directing, and supervising individuals or groups of employees so that their roles are effective and helping to realize the objectives of employees, companies and society.

Organizational culture

Organizational culture would want to achieve goals. To achieve these goals, the role of organizational culture in it is very important. With organizational culture we can improve the behavior and motivation of the employees themselves. According to Robbins (2008), that the idea of looking at organizations as culture, where there is a system of meaning that is shared by its members, is a relatively new phenomenon.

Meanwhile, according to Laudon (2012), all organizations have basic assumptions, which cannot be denied, and cannot be questioned (by their members) that explain the organization's goals and products. Organizational culture includes this set of assumptions about what products the organization must produce, how the organization produces them, where and for whom. According to Sudarmanto (2009), organizational culture is a general perception held by members of the organization, everyone in the organization must share with this perception in the same degree as a result, a dominant culture can occur, as well as several structures in all levels of a particular organization. According to Pratiwi et al (2014), organizational culture can be defined as a shared value system in an organization that determines the level of how employees carry out activities to achieve organizational goals.

Work Discipline

Work discipline has an important meaning for the company with the existence of work discipline on every employee in the company will make the company go forward, because employees who are disciplined in doing work can complete the tasks in the company even though it does not produce perfect work overall. . But in a certain period of time employees will do the work to be better.

The definition of work discipline put forward by experts, Hasibuan (2008), states that, discipline is the awareness and willingness of a person to obey all company regulations and applicable social norms. The above understanding can be concluded that what is meant by work discipline is a mental attitude that is reflected in the actions of individuals and groups in the form of obedience and obedience to the regulations established to reinforce organizational guidelines.

Employee performance

Employee performance is about how to manage the activities of an organization to achieve organizational goals. The success and success of an organization is determined by the quality of its human resources, leaders, and subordinates so that understanding and ability to operate performance management is a necessity.

According to Mangkunegara (2007), stating employee performance (work performance) is the work of quality and quantity achieved by an employee in carrying out their duties in accordance with the responsibilities given to him. According to M.hill (2007), stated that performance is an absolute necessity for an organization to achieve its goals by managing harmonious and integrated cooperation between leaders and subordinates. According to Mahsun (2006), stating performance is a picture of the level of achievement of the implementation of an activity / program / policy in realizing the goals, objectives, mission, and vision of the organization contained in strategic planning in an organization.

Conceptual Framework and Hypothesis Development

1. The Effect of Organizational Culture on Employee Performance.

2. Organizational culture is a pattern of basic assumptions created, discovered or developed by a group because it is dealing with the problem of adjusting the external environment and internal integration that has been running quite well, is considered valid and can therefore be taught to new members as an 
appropriate way to understand, think and feel when dealing with problems. Organizational culture can be interpreted as values, norms of beliefs adopted by members of the organization which are then developed, inherited where it will direct the behavior of each member and is useful to overcome internal and external problems that will be faced by the organization or members of the organization. According to the research conducted by Sulistyaningsih, et al (2012), organizational culture has a significant influence on employee performance.

2. Effect of Work Discipline on Employee Performance

Work discipline is an attitude of an employee in complying with all regulations that apply in a company voluntarily and with full awareness that aims for the survival of an organization or company in accordance with established goals. Work discipline has an important meaning for the company with the work discipline of every employee in the company will make the company go forward, because employees who are disciplined in doing work can complete the tasks in the company even though it does not produce work overall. Perfect. But within a certain period the employee will do the worker

The following is a picture of the framework of thought the influence of organizational culture and work discipline on employee performance.

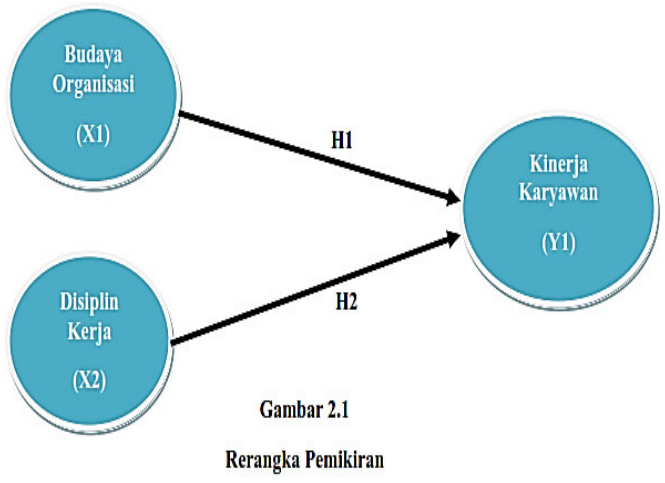

Hypothesis

The hypothesis is a temporary answer to the problem under study and its truth needs to be tested empirically. From this research the formulation of the problem, a central review and a review of the research, the hypothesis can be drawn from this research, namely:

1. Organizational culture influences employee performance

2. Work discipline has an effect on employee performance.

Research Methodology

The research process begins with the activity of identifying problems in the place that will be used as a research location, formulation of the identified problems, gathering theoretical basis that strengthens the foundation in variables, preparing methods for data collection, preparing instruments, and determining the statistical testing techniques used. In this process research time is needed from December 2018 to May 2019.

To obtain data for research, the authors take the place of research at PT. Sinarwijaya Ekapratista, research subjects are permanent employees at PT. Sinarwijaya Ekapratista. Variable Definition and Operations Based on the title of the proposal taken by the author, namely "Analysis of Organizational Culture and Work Discipline on Employee Performance", the authors define each variable and make operational variables.

Definition of Variables

Variables are anything in the form of what is determined by researchers to be studied in order to obtain information about it, then conclusions drawn. Or it can be interpreted as an attribute or nature or value of people, objects or activities that have certain variations determined by researchers to study and draw conclusions Sugiyono (2014).The Operational Definitions of the variables in this study are as follows:

a. Organizational culture

b. Work Discipline

c. Employee performance

Population

According to Sugiyono (2014), population is a generalization area that consists of objects or subjects that have certain qualities and characteristics determined by researchers to be studied and then drawn conclusions. It can be concluded that the population is an observation made by the researcher to look for conclusions from the study. The population in this study were 60 employees who continue to work at PT. Sinarwijaya Ekapratista.

Samples and Sampling Methods

Samples are part of the population taken in certain ways that also have certain characteristics, clear and complete that are considered to represent the population. 
According to Sugiyono (2014), the sample is part of the number and characteristics possessed by the population. The sample was conducted because of the limitations of researchers in conducting research both in terms of funding, time, energy, and a very large population. Therefore, the samples taken must be truly representative (representative). This study used a sample of 60 employees.

Means the sampling technique used is the saturation sampling technique (Census) as the technique for determining the sample. Saturated Sampling (Census) is a sampling technique when all members of the population are used as samples. So the sample used is 60 people, because the total population at PT. Sinarwijaya Ekapratista numbered 60 people.

Data Collection Techniques

In this study, researchers used data collection techniques is by field research (field research). Field research was conducted to determine the conditions that occur in the field more clearly and compare with the theories that have been obtained.

The data collection instrument used was a questionnaire. Questionnaire is an instrument of data collection which is done by giving a set of questions or written statements to respondents to answer (Sugiyono, 2014).

Data Types

The data that will be used in this study are primary data. Primary source data is data sources that can be obtained directly from those who provide data to data collection. As the data obtained, observed, and recorded directly by researchers directly from the company that is the object of research. Primary data in this study are questionnaire data from PT. Sinarwijaya Ekapratista regarding the influence of organizational culture and work discipline on employee performance.

Data analysis method

1. Descriptive Analysis

2. Partial Least Square

Evaluate Measurement (outer) Models

a. Convergent Validity

b. Discriminant Validity

c. Composite Reliability

d. Composite testing

Structural Model Testing / Hypothesis Testing (Inner Model)

Testing the inner model is the development of concept-based models and theories in order to analyze the relationship between variable exogenous and endogenous have a conceptual framework. Testing of models

\section{RESULTS AND DISCUSSION}

Taman Banjar Wijaya is a house developed by PT. Sinarwijaya Ekapratista, a subsidiary of PT. Duta Pertiwi.Tbk who is a member of the Sinarmas group. PT. Sinarwijaya Ekapratista was established in 1992 and started its business in the development of commercial areas, namely a number of housing units in the banjar wijaya park in 1994 in cooperation with PT. Wijaya Taman Banjar Wijaya also prepares a variety of entertainment facilities and sports centers that can be enjoyed around the Banjar Wijaya Park, not only that exclusive shopping centers are very easy to reach, such as Mall Tanggerang City, specifically for maintaining health, Tanggerang District Hospital is located not far, likewise the housing complex is very easy and fast to get to Soekarno Hatta airport. Vision of PT. Sinarwijaya Ekapratista is to be a winner in a competitive market with a main focus on customer satisfaction and professionalism. While the mission of PT Sinarwijaya Ekapratista is development for the development of quality of life and economic activities.

Characteristics of Respondents by Gender

Characteristics of respondents by sex can be seen in Table 4.1 below:

Tabel 4.1

Karakteristik Responden Berdasarkan Jenis Kelamin

\begin{tabular}{|c|c|c|c|}
\hline & & Frequency & Percent \\
\hline \multirow[t]{3}{*}{ Valid } & Perempuan & 12 & 20,0 \\
\hline & Laki-Laki & 48 & 80,0 \\
\hline & Total & 60 & 100,0 \\
\hline
\end{tabular}

Source: SPSS Processing Results 23

Based on the results of data processing in Table 4.1 shows that of the 60 respondents there were 12 respondents or $20 \%$ were female. While the remaining 48 respondents or $80 \%$ are male. Based on the data in Table 4.1 it can be seen that the majority of employees who work at PT. Sinarwijaya Ekapratista is male. 
Characteristics of Respondents by Age

Characteristics of respondents by age can be seen in Table 4.2 below:

Tabel 4.2

\section{Karakteristik Responden Berdasarkan Usia}

\begin{tabular}{|c|c|c|c|}
\hline & & Frequency & Percent \\
\hline \multirow[t]{5}{*}{ Valid } & $17-22$ tahun & 14 & 23,3 \\
\hline & $23-28$ tahun & 31 & 51,7 \\
\hline & 29-34 tahun & 13 & 21,7 \\
\hline & $35-40$ tahun & 2 & 3,3 \\
\hline & Total & 60 & 100,0 \\
\hline
\end{tabular}

Sumber : Hasil Pengolahan SPSS 23

Based on the results of data processing in Table 4.2 shows that of 60 respondents Who have ages 17 to 22 years as many as 14 respondents or $23.3 \%$, aged $23-38$

Years as many as 31 respondents or $51.7 \%$, aged 29 - 43 years, as many as 13

Respondents or $21.7 \%$ and respondents aged 35-40 years as many as 2 respondents Or 3.3\%. Thus the majority of employees who work at PT. Sinarwijaya Ekapratista is at the age of 23-28 years.

Characteristics of Respondents Based on Marital Status

Characteristics of respondents based on status can be seen in Table 4.3 below:

Tabel 4.3

Karakteristik Responden Berdasarkan Status Pernikahan

\begin{tabular}{|c|c|c|c|}
\hline & & Frequency & Percent \\
\hline Valid & Menikah & 26 & 43,3 \\
\hline & Belum Menikah & 34 & 56,7 \\
\hline & Total & 60 & 100,0 \\
\hline
\end{tabular}

Based on Table 4.3 shows that of the 60 respondents there were 26 respondents or $43.3 \%$ were married. While the remaining 34 respondents or $56.7 \%$ are single. It can be concluded that the majority of employees who work at PT. Sinarwijaya Ekapratista is not married yet.

Characteristics of Respondents Based on Education

Characteristics of respondents based on education can be seen in Table 4.4 below:

Tabel 4.4

Karakteristik Responden Berdasarkan Pendidikan

\begin{tabular}{|ll|l|l|}
\hline & & Frequency & Percent \\
\hline Valid & SMP & 11 & 18,3 \\
& SMA/Sederajat & 47 & 78,3 \\
D3 & 2 & 3,3 \\
& Total & 60 & 100,0 \\
\hline
\end{tabular}

Sumber : Hasil Pengolahan SPSS 23

Based on the data in Table 4.4 shows that of the 60 respondents, the number of respondents who have junior high school education is 11 respondents or $18.3 \%$, high school education is 47 respondents or $78.3 \%$, with D3 education is 2 respondents or $3.3 \%$. Thus the majority of employees at PT. Sinarwijaya Ekapratista has a high school education with a percentage of $78.3 \%$. Characteristics of Respondents

Based on Length of Work

Characteristics of respondents based on length of work can be seen in Table 4.5 below: 
Tabel 4.5

Karakteristik Responden Berdasarkan Lama Bekerja

\begin{tabular}{|c|c|c|c|}
\hline & & Frequency & Percent \\
\hline \multirow[t]{5}{*}{ Valid } & $<1$ tahun & 14 & 23,3 \\
\hline & $1-5$ tahun & 36 & 60,0 \\
\hline & $6-10$ tahun & 8 & 13,3 \\
\hline & $>10$ tahun & 2 & 3,3 \\
\hline & Total & 60 & 100,0 \\
\hline
\end{tabular}

Based on the data in Table 4.5 shows that of the 60 respondents, the number of respondents who worked less than 1 year was 14 respondents or $23.3 \%$, worked 1 to 5 years as many as 36 respondents or $60 \%$, worked 6 to 10 years as many as 8 respondents or $13,3 \%$ and worked more than 10 years by 2 respondents or $3.3 \%$. Thus the majority of employees at PT. Sinarwijaya Ekapratist has a working period of 1 to 5 years with a percentage of $60 \%$.

Characteristics of Respondents Based on Income

Characteristics of respondents based on income can be seen in Table 4.6 below:

Tabel 4.6

Karakteristik Responden Berdasarkan Penghasilan

\begin{tabular}{|c|c|c|c|}
\hline & & Frequency & Percent \\
\hline \multirow[t]{3}{*}{ Valid } & Rp. 1.00 .000 sd Rp. 4. 000.000 & 54 & 90,0 \\
\hline & Rp. 4.000 .000 sd Rp. 6.000 .000 & 6 & 10,0 \\
\hline & Total & 60 & 100,0 \\
\hline
\end{tabular}

Sumber : Hasil Pengolahan SPSS 23

Based on the data in Table 4.6 shows that of the 60 respondents, the number of respondents earning 1 to 4 million rupiah was 54 respondents or $90 \%$ and those earning 4 to 6 million rupiah were 6 respondents or $10 \%$. Thus the majority of employees of PT. Sinarwijaya Ekapratista has an income of 1 to 4 million rupiah per month.

Characteristics of Questionnaire Answers

Questionnaire Characteristics Based on Organizational Culture Variables

The characteristics of the questionnaire based on organizational culture variables can be seen in Table 4.7 below:

Tabel 4.7

Karakteristik Kuesioner Variabel Budaya Organisasi

\begin{tabular}{|l|r|r|r|r|}
\hline & $\mathrm{N}$ & Minimum & Maximum & Mean \\
\hline $\mathrm{BO} 1$ & 60 & 3 & 5 & 4,08 \\
$\mathrm{BO} 2$ & 60 & 3 & 5 & 4,40 \\
$\mathrm{BO} 3$ & 60 & 3 & 5 & 4,07 \\
$\mathrm{BO} 4$ & 60 & 3 & 5 & 4,40 \\
$\mathrm{BO}$ & 60 & 3 & 5 & 4,35 \\
$\mathrm{BO6}$ & 60 & 3 & 5 & 4,47 \\
$\mathrm{BO}$ & 60 & 3 & 5 & 4,15 \\
$\mathrm{BO}$ & 60 & 4 & 5 & 4,45 \\
BO9 & 60 & 3 & 5 & 4,55 \\
BO10 & 60 & 4 & 5 & 4,18 \\
BO11 & 60 & 3 & 5 & 4,30 \\
Valid N (listwise) & 60 & & & \\
\hline
\end{tabular}

Sumber : Hasil Pengolahan SPSS 23

Characteristics of Questionnaires Based on Work Discipline Variables

The characteristics of the questionnaire based on work discipline variables can be seen in Table 4.8 below: 
Tabel 4.8

Karakteristik Kuesioner Variabel Disiplin Kerja

\begin{tabular}{|l|r|r|r|r|}
\hline & $\mathrm{N}$ & Minimum & Maximum & Mean \\
\hline DK1 & 60 & 3 & 5 & 4,08 \\
DK2 & 60 & 3 & 5 & 4,10 \\
DK3 & 60 & 3 & 5 & 4,15 \\
DK4 & 60 & 3 & 5 & 4,33 \\
DK5 & 60 & 3 & 5 & 4,55 \\
DK6 & 60 & 3 & 5 & 4,82 \\
DK7 & 60 & 3 & 5 & 4,40 \\
Valid N (listwise) & 60 & & & \\
\hline
\end{tabular}

Sumber : Hasil Pengolahan SPSS 23

Questionnaire Characteristics Based on Employee Performance Variables

The characteristics of the questionnaire based on work discipline variables can be seen in Table 4.9 below: Tabel 4.9

Karakteristik Kuesioner Variabel Kinerja Karyawan

\begin{tabular}{|l|r|r|r|r|}
\hline & N & Minimum & Maximum & Mean \\
\hline KK1 & 60 & 3 & 5 & 4,08 \\
KK2 & 60 & 3 & 5 & 4,37 \\
KK3 & 60 & 3 & 5 & 4,22 \\
KK4 & 60 & 3 & 5 & 4,28 \\
KK5 & 60 & 3 & 5 & 4,45 \\
KK6 & 60 & 3 & 5 & 4,57 \\
KK7 & 60 & 3 & 5 & 4,23 \\
KK8 & 60 & 3 & 5 & 4,07 \\
KK9 & 60 & 3 & 5 & 4,40 \\
KK10 & 60 & 3 & 5 & 4,40 \\
Valid N (listwise) & 60 & & & \\
\hline
\end{tabular}

D. Data Analysis Methods: Component Based Structural Equation Modeling

Component / variance Based Structural Equation Modeling is an alternative to covariance based SEM, this component or variance based SEM is known as Partial Least Square (PLS). This method is intended for causalpredictive analysis in situations of high complexity and low theoretical support. PLS has the aim to find predictive linear relationships between variables (component based predictive models) (Ghozali, 2014). The testing steps undertaken for the fulfillment of variance based SEM assumptions are guidelines for modeling variance based SEM both in the process of data collection and data processing using SmartPLS 3.

Evaluation of Measurement Model (Outer Model)

a) Convergent Validity

Convergent Validity testing of the measurement model with reflexive indicators is valued based on the correlation between item score / component score and construct score calculated by PLS. Individual indicators are considered valid if they have a correlation value above 0.70 . However, at the scale development research stage, loading factors of 0.50 to 0.60 are still acceptable. By looking at the output of the correlation between the indicator and its construct as shown in the table and structural picture below: 
Tabel 4.10

Hasil Pengujian Convergent Validity

\begin{tabular}{|c|c|c|c|}
\hline Variabel & Indikator & Outer Loading & Keterangan \\
\hline \multirow{11}{*}{$\begin{array}{l}\text { Budaya Organisasi } \\
\text { (X1) }\end{array}$} & $\mathrm{BO} 1$ & 0,691 & Valid \\
\hline & $\mathrm{BO} 2$ & 0,816 & Valid \\
\hline & $\mathrm{BO} 3$ & 0,648 & Valid \\
\hline & $\mathrm{BO} 4$ & 0,575 & Valid \\
\hline & BO5 & 0,832 & Valid \\
\hline & $\mathrm{BO6}$ & 0,272 & Tidak Valid \\
\hline & $\mathrm{BO} 7$ & 0,359 & Tidak Valid \\
\hline & $\mathrm{BO} 8$ & 0,482 & Tidak Valid \\
\hline & BO9 & 0,640 & Valid \\
\hline & $\mathrm{BO} 10$ & 0,114 & Tidak Valid \\
\hline & BO11 & $-0,225$ & Tidak Valid \\
\hline \multirow{7}{*}{ Disiplin Kerja (X2) } & DK1 & 0,756 & Valid \\
\hline & DK2 & 0,283 & Tidak Valid \\
\hline & DK3 & 0,399 & Tidak Valid \\
\hline & DK4 & 0,541 & Valid \\
\hline & DK5 & 0,618 & Valid \\
\hline & DK6 & 0,043 & Tidak Valid \\
\hline & DK7 & 0,849 & Valid \\
\hline \multirow{10}{*}{$\begin{array}{c}\text { Kinerja Karyawan } \\
\text { (Y1) }\end{array}$} & KK1 & 0,719 & Valid \\
\hline & KK2 & $-0,307$ & Tidak Valid \\
\hline & KK3 & $-0,003$ & Tidak Valid \\
\hline & KK4 & $-0,347$ & Tidak Valid \\
\hline & KK5 & $-0,516$ & Tidak Valid \\
\hline & KK6 & 0,558 & Valid \\
\hline & KK7 & $-0,270$ & Tidak Valid \\
\hline & KK8 & 0,661 & Valid \\
\hline & KK9 & 0,539 & Valid \\
\hline & KK10 & 0,857 & Valid \\
\hline
\end{tabular}

Sumber : Output PLS

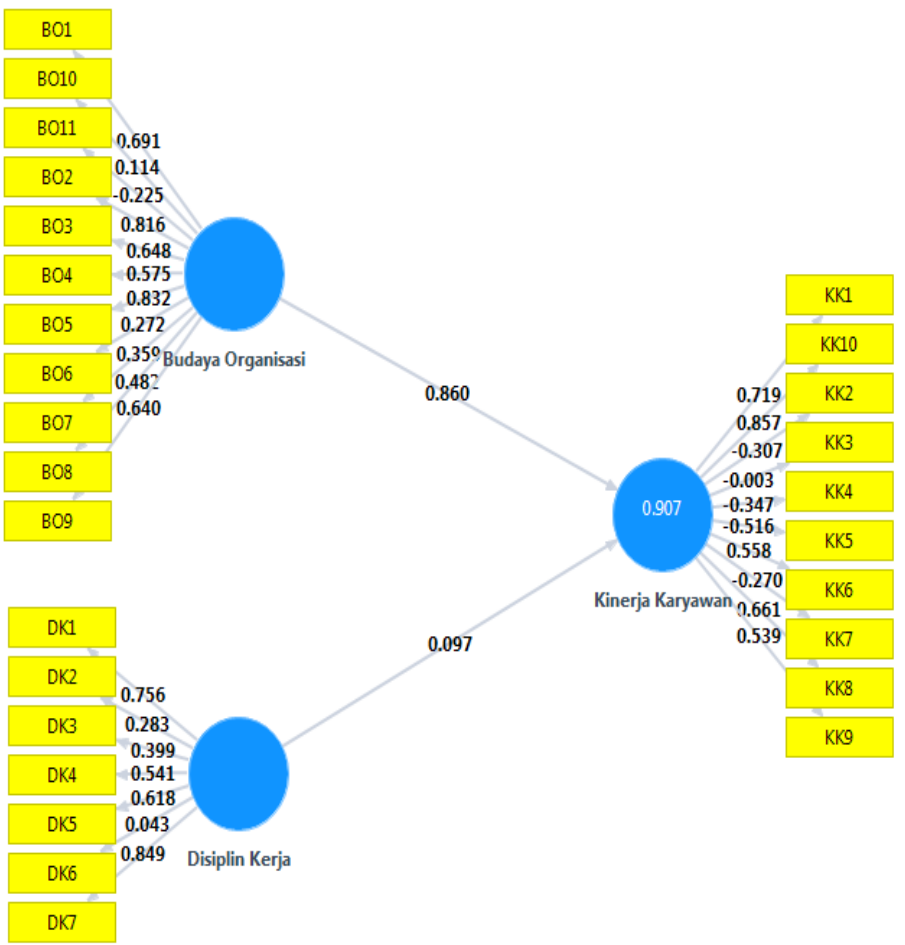

Based on Table 4.10 and Figure 4.1, it can be seen that indicators BO6, BO7, BO8, BO10, BO11, DK2, DK3, DK6, KK2, KK3, KK4, KK5, KK7 have loading factor values less than 0.50 . Therefore, the indicator will be removed from the model. Here are the outputs from the omission indicators and recalculation: 
Tabel 4.11

Hasil Pengujian Convergent Validity (Modifikasi Pertama)

\begin{tabular}{|c|c|c|c|}
\hline \multirow{2}{*}{ Variabel } & Indikator & $\begin{array}{c}\text { Outer } \\
\text { Loading }\end{array}$ & Keterangan \\
\hline \multirow{4}{*}{$\begin{array}{c}\text { Budaya } \\
\text { Organisasi } \\
\text { (X1) }\end{array}$} & BO1 & 0,728 & Valid \\
\cline { 2 - 4 } & BO2 & 0,825 & Valid \\
\cline { 2 - 4 } & BO3 & 0,613 & Valid \\
\cline { 2 - 4 } & BO4 & 0,606 & Valid \\
\cline { 2 - 4 } & BO5 & 0,848 & Valid \\
\cline { 2 - 4 } & BO9 & 0,631 & Valid \\
\hline \multirow{4}{*}{$\begin{array}{c}\text { Disiplin Kerja } \\
\text { (X2) }\end{array}$} & DK1 & 0,824 & Valid \\
\cline { 2 - 4 } & DK4 & 0,540 & Valid \\
\cline { 2 - 4 } & DK5 & 0,570 & Valid \\
\cline { 2 - 4 } & DK7 & 0,848 & Valid \\
\hline \multirow{4}{*}{$\begin{array}{c}\text { Kinerja Karyawan } \\
\text { (Y1) }\end{array}$} & KK1 & 0,783 & Valid \\
\cline { 2 - 4 } & KK8 & 0,648 & Valid \\
\cline { 2 - 4 } & KK9 & 0,565 & Valid \\
\cline { 2 - 4 } & KK10 & 0,576 & Valid \\
\hline
\end{tabular}

Sumber : Output PLS

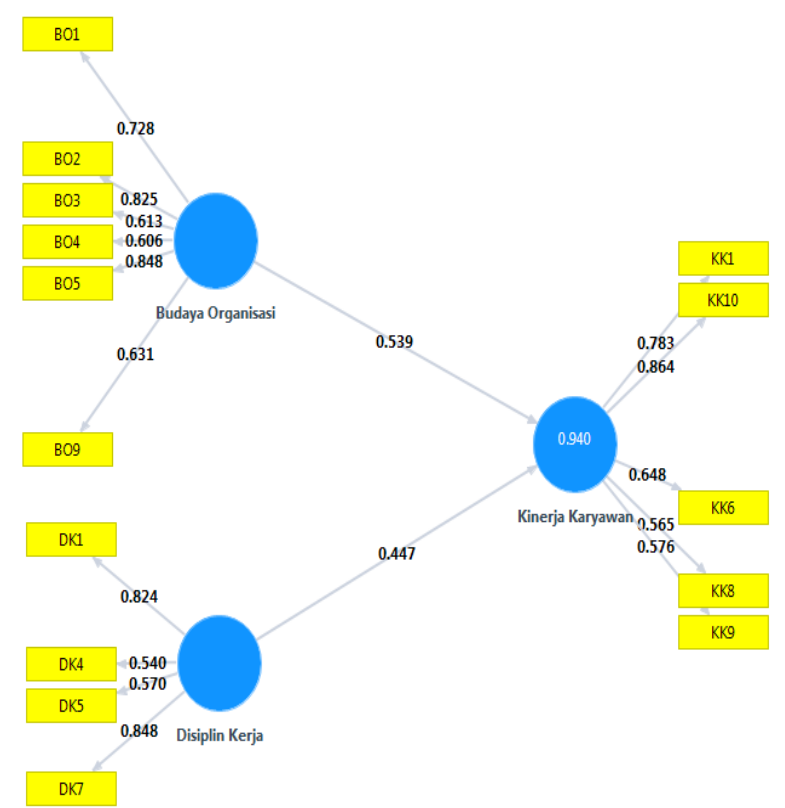

Figure 4.2

PLS Algorithm Results (First Modification)

The results of the second modification of the convergent validity test in Table 4.11 and Figure 4.2 can be seen that all indicators meet the convergent validity because it has a loading factor value above 0.50 .

Discriminant Validity

Discriminant validity testing, reflective indicators seen in the cross loading between the indicator with the construct. An indicator is declared valid if it has the highest loading factor to the intended construct compared to the loading factor to other constructs. Thus, latent constructs predict indicators in their blocks better than indicators in other blocks.

Composite Reliability and Cornbachs Alpha

Composite reliability testing aims to test the validity of the instrument in a research model. Or measure internal consistency and the value must be above 0.60 . If all latent variable values have composite reliability and cronbach's alpha $\geq 0.7$, it means that the construct has good reliability or the questionnaire used as a tool in this study has 
been reliable or consistent.

Tabel 4.12

Composite Reliability

\begin{tabular}{|l|c|c|}
\hline \multicolumn{1}{|c|}{ Variable } & Composite Reliability & remarks \\
\hline Organizational culture (X1) & 0,861 & Reliable \\
Discipline (X2) & 0,796 & Reliable \\
performance(Y1) & 0,821 & Reliable \\
\hline
\end{tabular}

Tabel 4.13

Cornbach Alpha

\begin{tabular}{|l|c|c|}
\hline \multicolumn{1}{|c|}{ Variabel } & $\begin{array}{c}\text { Cornbach } \\
\text { Alpha }\end{array}$ & Remarks \\
\hline culture (X1) & 0,805 & Reliable \\
discipline(X2) & 0,665 & Tidak Reliable \\
Performance (Y1) & 0,725 & Reliable \\
\hline
\end{tabular}

Source: PLS Output

Based on Table 4.12 that the results of composite reliability testing show satisfactory values, because all latent variable values have composite reliability values $\geq 0.7$. But on the other hand, in Table 4.13 the results of the Cornbach Alpha test show an unsatisfactory value, namely there is one latent variable (work discipline) that is not yet reliable because itan alpha Cornbachs value below $0.7(<0.7)$. It appears that the cornbachs alpha value does not meet the criteria, but according to Sugiyono (2009), using the degree of reliability as follows:

$0.80-1.00$ the degree of reliability is very high

$0.60-0.79$ Degree of high reliability

$0.40-0.59$ Degree of moderate reliability

0.20 - 0.39 Degree of low reliability

$0.00-0.19$ the degree of reliability is very low

Based on the above degree of reliability, the Cornbachs alpha value of the work discipline variable of 0.665 can be said to be reliable, because the value is at a high degree of reliability.

Tabel 4.14

Cornbach Alpha

\begin{tabular}{|l|c|c|}
\hline \multicolumn{1}{|c|}{ Variable } & Cornbach & re \\
\hline Culture(X1) & Alpha & Very high \\
Discipline (X2) & 0,805 & High \\
Performance (Y1) & 0,665 & High \\
\hline
\end{tabular}

Sumber : Output PLS

2. Structural Model Testing / Hypothesis Testing (Inner Model)

Testing the inner model is the development of models based on concepts and theories in order to analyze the relationship between exogenous and endogenous variables that have been described in the conceptual framework. The stages of testing the structural model (inner model) are carried out with the following steps:

R-square value

See the R-square value which is a test of goodness of fit model.

Tabel 4.15

$\mathbf{R}^{2}$ Variabel Endogen

\begin{tabular}{|c|c|}
\hline Variabel Endogen & R-square \\
\hline Performance (Y1) & 0,940 \\
\hline
\end{tabular}

Sources: Output PLS

Structural models indicate that the model on the Employee Performance variable can be said to be good because it has the value above (0) (Uce indahyanti, 2013). The model of the influence of independent latent variables (Organizational Culture and Work Discipline) on Employee Performance gives an R-square value of 0.940 which can be interpreted that the construct variability of Employee Performance can be explained by the constructability variability of Organizational Culture and Work Discipline by $94 \%$ while $6 \%$ is explained by variables other than those studied.

Goodness of Fit Model

Testing the Goodness of Fit Structural models in the inner model using the value of predictive-relevance (Q2). Qsquare value greater than 0 (zero) indicates that the model has a predictive-relevance value. The R-square value of each endogenous variable in this study can be seen in the following calculations:

Predictive-relevance value is obtained by the formula: 
$\mathrm{Q} 2=1--(1-\mathrm{R} 1)$

$\mathrm{Q} 2=1-(1-0.940)$

$\mathrm{Q} 2=1-0.06$

$\mathrm{Q} 2=0.940$

The calculation results above show a predictive-relevance value of 0.940 or a Q-square value of more than zero (0). That means that $94 \%$ of the variation in Employee Performance variables (the dependent variable) is explained by the variables used. Thus the model is said to have a relevant predictive value.

Hypothesis Testing Results

The estimated value for the path relationship in the structural model must be significant. This significant value can be obtained by the boostrapping procedure. See the significance of the hypothesis by looking at the value of the parameter coefficient and the significance value of the T-statistics on the boostrapping report algorithm. To find out the significant or insignificant seen from the T-table at alpha $0.05(5 \%)=1.96$, then the T-table is compared by the T-count (T-statistic).

Tabel 4.16

Hasil Pengujian Hipotesis

\begin{tabular}{|c|c|c|c|c|}
\hline & $\begin{array}{c}\text { Original } \\
\text { Sampel }\end{array}$ & $\begin{array}{c}\text { Standar } \\
\text { Deviation }\end{array}$ & T Statistic & Keterangan \\
\hline $\begin{array}{c}\text { Budaya Organisasi -> } \\
\text { Kinerja Karyawan }\end{array}$ & 0,539 & 0,114 & 4,711 & $\begin{array}{c}\text { Positif - } \\
\text { Signifikan }\end{array}$ \\
\hline $\begin{array}{c}\text { Disiplin Kerja -> Kinerja } \\
\text { Karyawan }\end{array}$ & 0,447 & 0,116 & 3,854 & $\begin{array}{c}\text { Positif - } \\
\text { Signifikan }\end{array}$ \\
\hline
\end{tabular}

Sumber : Output PLS

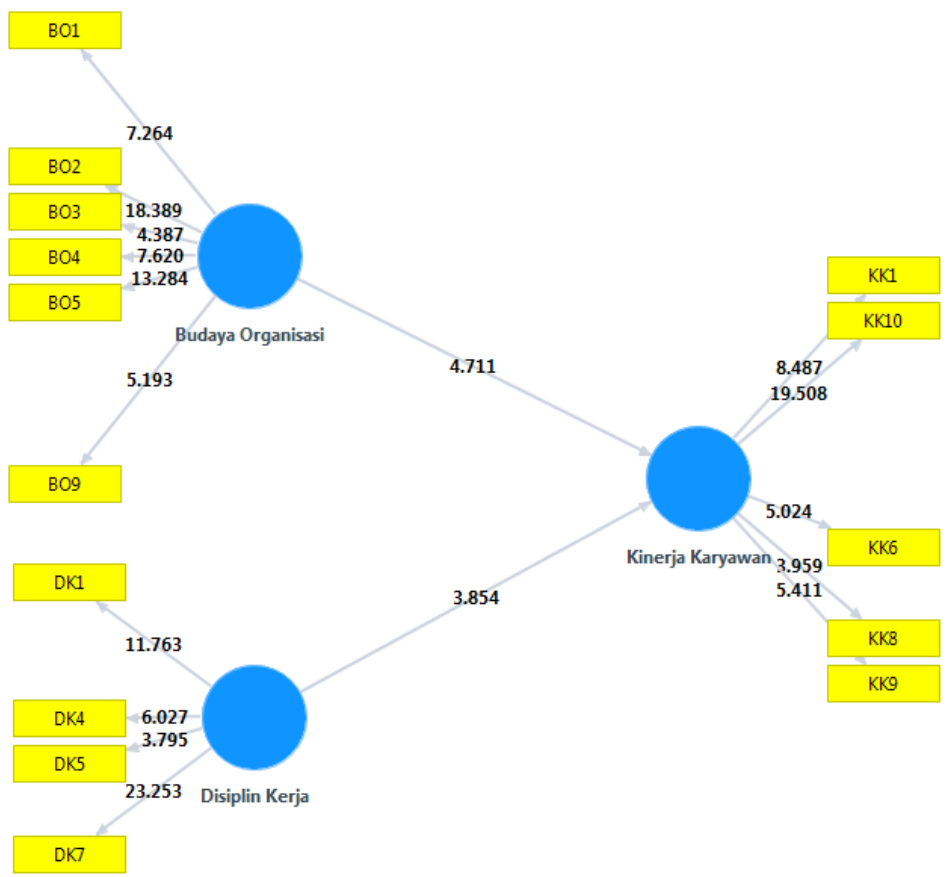

\section{Discussion}

1. The Effect of Organizational Culture on Employee Performance

Based on the hypothesis test in this study shows the results that organizational culture has a positive and significant effect on employee performance. The results of this hypothesis are strengthened by the research of Sulistyaningsih (2012), proving that organizational culture has a positive and significant effect on employee performance. This is likely due to the current organizational culture that makes employees bored with the organizational culture imposed by the company. So that employees are more concerned with personal interests rather than the company's vision and mission. And this is also a possibility that causes the performance of employees at PT. Sinarwijaya Ekapratista 
is low.

Effect of Work Discipline on Employee Performance

Based on the hypothesis test in this study showed the results that organizational culture has a positive and significant effect on employee performance. The results of this study agree with the results of Chirasha (2013), proving that work discipline has a positive and significant effect on employee performance. This is likely due to the work discipline applied by the company to employees which are less clear, both in terms of rewards or vice versa in the form of punishment. And this is also a possibility that causes the performance of employees at PT. Sinarwijaya Ekapratista is low.

\section{Conclusion}

This study tries to analyze the variables related to the influence of organizational culture and work discipline on employee performance at PT. Sinarwijaya Ekapratista. From the research results obtained from the calculation of data processing using Partial Least Square (PLS), the following conclusions can be drawn:

1. Organizational culture has a direct and positive and significant effect on employee performance at PT. Sinarwijaya Ekapratista.

2. Work discipline has a direct and positive and significant effect on employee performance at PT. Sinarwijaya Ekapratista.

\section{Suggestions}

We recommend that PT. Sinarwijaya Ekapratista provides psychological training or approach to the importance of organizational culture in a company to employees, so that employees understand the importance of an organizational culture in a company, and if it still cannot improve the organizational culture within PT. Sinarwijaya Ekapratista, the company must be willing to change the organizational culture that is currently being carried out, for example by replacing the briefing system by playing soccer (futsal) or other sports on weekends (weekend), the purpose of this is to tie the togetherness between employees, due to how Even the organizational culture will run well if it is properly implemented by all employees who work in the company. So that employees can put forward the company's vision and mission rather than personal interests. So that the behavior and activities carried out by employees reflect the organizational culture at PT. Sinarwijaya Ekapratista.

PT. Sinarwijaya Ekapratista should give awards in the form of bonuses for employees who have a good level of work discipline, so that the work discipline process can be better and employees are even more motivated to improve their work discipline, In addition to the imposition of stricter sanctions against undisciplined employees Suggestions for further research in order to further research with different company objects, by redeveloping variables and indicators that have not been used in this study and researchers are advised to choose industries engaged in other fields that are willing to provide more information to researchers for research in order to make it easier to get data needed by researchers.

\section{REFERENCES}

Ade Permata Surya dkk, ( 2017) Pengaruh Perceived Service Quality dan E-Service Quality terhadap Repurchase Intention dengan customer satisfaction sebagai variabel interventing Studi kasus : Grab di Indonesia , Jurnal

Amiroso.J dkk 2015 Influence of Discipline, Working Environment, Culture of Organization and Competence on Workers' Performance through Motivation, Job Satisfaction (Study in Regional Development Planning Board of Sukoharjo Regency) 2015, Jurnal International

Ernawati (2018) Pengaruh Budaya Organisasi terhadap kinerja pegawai pada kantor PT.Telkom di Samarinda, Jurnal

Fauziah Jenny. (2016). "Pengaruh Budaya Organisasi, Pengembangan Karir dan Self Efficacy Terhadap Kinerja Karyawan”. Jurnal Manajemen, Vol.08 No:1 (2085-6911)

Katiandagho, (2014). "Pengaruh Disiplin Kerja, Kepemimpinan dan Motivasi Terhadap Kinerja Pegawai Pada PT. PLN (PERSERO) Wilayah Suluttenggo Area Manado”.Jurnal EMBA Vol.02 No:3 (1593-1602).

MN. Nurasman dkk 1 ,2018, The Influence of Organizational Culture and Work Motivation Toward Employee Performance (Case Study On Employees of PT. Inoac Polytechno Indonesia) 2018, Jurnal International.

Parashakti, Ryani Dhyan.(2017) Determinants of Employee's Dicipline and Motivation :Evidence from Bank Indonesia. Jakarta, International Journal of Economic Perspectives, volume 11, Issue 1,1598-1607.Jurnal

Parisa Aasi. (2014)."The Influence of Organizational Culture on IT Governance Performance: Case of the IT Department in a Large Swedish Company”. International Journal of IT/Business Alignment and Governance, Vol.No:5 (34-49).

(http://onlineresearchjournals.org/JSSpdf/2013/jul/Chirasha.pdf)

Pratiwi, Dkk. (2014). "Pengaruh Lingkungan Kerja dan Budaya Organisasi Terhadap Kinerja Karyawan PT. 
Bank Riau Kepri Capem Duri”. Jom FEKON. Vol.1 No:2.

Sandy Kurniawan. (2015). Pengaruh Budaya Organisasi Dan Disiplin Kerja Terhadap Kinerja Pegawai Pada Kantor Badan Pemberdayaan Masyarakat Dan Pemerintah Desa Kabupaten Kutai Timur, eJournal Pemerintahan Integratif Vol.3, No:3 (451-463).

Simanjuntak.R.P dkk , 2015 Pengaruh Budaya Organisasi dan Disiplin Kerja Terhadap Kinerja Karyawan PT .Kereta Api Indonesia (Persero) DAOP IV Semarang Jurnal

Sugiyono. (2014). Metode Penelitian Kuantitatif, Kualitatif, dan Kombinasi (Mixed Methods).Bandung: Alfabeta. Widodo, SE. (2015). Manajemen Pengembangan Sumber Daya Manusia. Yogyakarta: Pustaka Pelajar. 